\title{
Impact Behavior of Aramid Reinforced Polymer Matrix Composites Produced By Hot Press-Prepreg Method
}

\author{
Ertan Kösedağ ${ }^{1 *}$, Recep Ekici ${ }^{2}$ \\ ${ }^{1 *}$ Van Yuzuncu Yil University, Faculty of Engineering, Departmant of Mechanical Engineering, Van, Turkey, (ORCID: 0000-0002-5580-0414), ekosedag@yyu.edu.tr \\ ${ }^{2}$ Erciyes University, Faculty of Engineering, Departmant of Mechanical Engineering, Kayseri, Turkey, (ORCID: 0000-0002-4420-8431), rekici@erciyes.edu.tr
}

(1st International Conference on Applied Engineering and Natural Sciences ICAENS 2021, November 1-3, 2021)

(DOI: 10.31590 /ejosat.)

ATIF/REFERENCE: Kösedağ, E. \& Ekici, R. (2021). Impact Behavior of Aramid Reinforced Polymer Matrix Composites Produced By Hot Press-Prepreg Method. European Journal of Science and Technology, (28), 84-90.

\begin{abstract}
In this study, the production of polymer matrix composite material from prepreg with a hot press, which is a different method from the classical autoclave method, was optimized. The impact behavior of the composite materials produced was investigated. For this, $3 \mathrm{~mm}$ thick and $90 \mathrm{~mm}$ diameter aramid reinforced polymer matrix composite samples were produced by hot press method. Impact tests were carried out at $15,30,45 \mathrm{~J}$ energy values. For the impact tests, a $10 \mathrm{~mm}$ radius semi-cylindrical steel tip was used. The weight of this tip is $5,045 \mathrm{~kg}$. With the impact tests, the contact force time and energy time curves of the composite samples were obtained and the impact behaviors were interpreted from there. Accordingly, as the impact energy increased, there was an increase in the maximum contact forces of the composite samples and a decrease in the contact times. Considering the energy time graphs, it was determined that there was a decrease in the amount of absorbed energy of the samples as the impact velocity applied to the composite samples increased. Besides, considering the ratio of absorbed energy to applied energy, it was observed that the energy absorption ability dramatically decreased as the impact velocity increased. Finally, the densities of the composite samples produced with the hot press were determined according to the Archimedes principle.
\end{abstract}

Keywords: Aramid reinforced polymer matrix composite, Density, Low velocity impact, Hot-Press, Prepreg.

\section{Sıcak Pres-Prepreg Yöntemi ile Üretilmiş Aramit Takviyeli Polimer Matrisli Kompozitlerin Darbe Davranışlarının İncelenmesi}

Öz

Bu çalışmada klasik autoklav yönteminden farklı olarak sıcak pres ile prepregten kompozit malzeme üretilebilirliği üzerinde çalışılmış ve elde edilen polimer matrisli kompozitlerin darbe davranışları incelenmiştir. Bunun için 3mm kalınlığında 90 mm çapında aramit takviyeli polimer matrisli kompozit malzemeler sıcak pres yöntemi ile üretilmiştir. Darbe davranışı karekterizasyonu içim 15, 30, 45J enerjiye sahip düşük hızlı darbe testleri gerçekleştirilmiştir. Darbe testlerinde $10 \mathrm{~mm}$ yarıçaplı yarı silindirik çelik uç kullanıldı. Kullanılan çelik ucun ağırlığı 5.045 kg dır. Darbe testlerinden elde edilen temas kuvveti-zaman ve enerji-zaman eğrileri dikkate alınarak kompozit malzemelerin darbe dirençleri yorumlanmıştır. Buna göre, darbe enerjisinin artması ile maksimum temas kuvvetinde bir artış gözlemlenirken temas süresinde bir azalma tespit edilmiştir. Enerji zaman eğrileri değerlendirildiğinde, darbe enerjisinin artması ile kompozit numunelerin absorbe ettikleri enerji miktarında bir azalış olduğu görülmektedir. Bunun yanında, absorbe edilen enerjinin uygulanan darbe enerjisine oranı dikkate alındığında darbe enerjisinin artması ile bu oranda ciddi miktarda düşüş olduğu gözlemlenmiştir. Son olarak kompozit numunelerin darbe sonrası görüntüleri sunulmuş ve sıcak pres ile üretilen bu aramit takviyeli polimer matrisli kompozitlerin yoğunlukları deneyes olarak Arşimet prensibini baz alarak çalışan yoğunluk olçme cihazı ile tespit edilmiştir.

Anahtar Kelimeler: Aramit takviyeli polimer matrisli kompozit, Düşük hızlı darbe, Prepreg, Sıcak pres, Yoğunlık.

* Corresponding Author: ekosedag@yyu.edu.tr 


\section{Introduction}

The rapid development of the industry creates the need for materials with new properties. Due to the fact that monolithic materials such as metal, polymer ceramics cannot meet the needs, the composite material approach has been put forward. In the last few decades, interest in polymer matrix composite (PMC) materials has been increasing, especially in the automotive, aviation and marine industries. The reason why composite materials are so important and preferable is the features they have and the advantages they provide. Some of the advantages of PMC materials; specific strength, low density, high corrosion resistance, etc. can be sorted [1-3]. However, the PMC have low fracture toughness unlike metals, making them susceptible to impact loads. Therefore, researching the impact behavior of PMC plates and increasing their resistance to impact loads has become an important issue in terms of design, safety and engineering applications. Damage to metal structures exposed to impact usually starts on the surface and can be detected with the naked eye [4-6]. On the other hand, in polymer matrix composites, this damage occurs in the form of delamination, fiber breakage and matrix cracking, which often takes place inside the structure and cannot be detected with the naked eye. In addition, impact effects at low and medium velocity can be absorbed by metals in an elastic and plastic manner, while plastic deformation due to the energy absorbed in polymer matrix composites is extremely low. Therefore, characterizing the impact behavior of PMC materials is extremely important. Some studies investigating the impact behavior of PMC materials are as follows.

Berk et al. [7] found in their study that S2 glass / epoxy composite samples absorb more energy than aramid / epoxy composite samples, considering the puncture threshold. Besides, for 30J impact energy, rebound condition occurred for S2glass/epoxy samples, whereas puncture was observed for aramid/epoxy ones. To investigate the reaction of PMC to impact, Xiaofei et al. [8] conducted a study and observed that fiber breakage is very limited, while matrix cracking and delamination are the main damage mechanisms. In addition, matrix damage in the upper layers; they stated that it is mainly caused by compressive stress and tensile stress in the lower layers. The low velocity effect caused delamination in only a few interlayers. They found that there was no distortion in the middle area due to the normal compressive stress applied by the impactor. In another study, Sayer [9] experimentally investigated the impact behavior of glass-fiber/epoxy and hybrid composite plates such as aramid fiber-glass fiber/epoxy, aramid fiber-carbon fiber/epoxy and carbon fiber-glass fiber/epoxy plates at increasing impact energies at room temperature. It has been found that increasing the number of carbon layers at room temperature has little effect on increasing the puncture limit value for hybrid composites. Belevi and Inançer [10] investigated the impact behavior of hybrid composites with different temperature and increasing impact energy. They observed that the behavior of composite materials changed at different temperatures and striker velocity. Gustin et al. [11] investigated the impact, post-impact compression and tensile strength behaviors of carbon fiber and kevlar sandwich composites. The bottom face plates are made entirely of carbon fiber to maintain the overall flexural rigidity of the sandwich composite. Experimentally obtained results helped define the advantages and disadvantages of replacing carbon fiber sheets with kevlar or hybrid. Uyaner and Kara [12] investigated the effects of plate dimensions on damage in laminated composites subjected to low velocity impact. As a result, they observed that as the sample width increases, the contact force increases and the amount of permanent displacement on the test samples decreases on the material. Yapici et al. [13] carried out a study about the dynamic behavior of e-glass/epoxy composite sheets subjected to low velocity impact using the finite element method. As a result of the finite element analysis; velocity-time, acceleration-time, force-time, displacement-time and kinetic energy-time changes are given in graphs. Salehi-Khojin et al. [14] investigated the impact tests of layered kevlar/glass-fiber composites at variable temperatures $\left(-50^{\circ}\right.$ to $\left.120^{\circ} \mathrm{C}\right)$ and low velocities. They also examined the results of maximum energy, elastic energy, maximum collapse, maximum impact force, ductility under the effect of temperature after impact. In the study conducted by Özeş and Taşkın [15], the impact behaviors of two composites produced with jute fabric and wool felt reinforcement were investigated. In order to increase the surface adhesion properties, the jute fabrics were kept in $10 \% \mathrm{NaOH}$ solution for 4 hours and then left to dry at room temperature. Composites were produced in the same thickness by vacuum infusion method. Composite specimens were tested at three energy levels to determine their impact strength. The results showed that the damage was less in wool felt reinforced composite under the same impact load.

In this study, aramid fiber reinforced PMC materials were obtained from prepreg using a hot press with a different approach. Thus, unlike autoclave, its manufacturability with hot press is optimized. Impact tests at three different energy were applied to PMC materials of equal thickness produced under the same conditions and the energy absorption capabilities of these materials were examined. Post-impact composite specimen images are presented. In addition, the densities of the produced composite specimen were measured experimentally.

\section{Material and Method}

Prepreg is the pre-prepared epoxy resin and hardener components impregnated with the fiber fabric. In the production method with prepreg, the mixture of epoxy resin and hardener is impregnated with the fiber fabric, and the fabric, which is impregnated with the mixture prepared according to the amount and type of epoxy and hardener used, can be stored at room temperature for a certain period of time without curing, without deteriorating its structure. The special formulation of the epoxy ensures that the curing process is significantly slow at ambient temperature and almost completely stopped at freezing temperatures. Since the prepreg is cut as the final product, material consumption and composite cutting costs are avoided. In addition, it is less harmful to human health in terms of smell and reaction compared to other methods. The disadvantages of producing with prepreg are that the shelf life of the prepreg is low, that is, it must be converted into a product immediately after being prepreg.

Autoclave is used to obtain composite from prepreg. Autoclave gives optimum results as it performs compaction and curing process at the same time, but autoclave is a very expensive production equipment. For this reason, alternative ways are tried to produce composite from prepreg, the main thing is to compress the fiber so that there is no gap in it and to cure it at the appropriate temperature for the appropriate time. During production, the load on the prepreg by vacuum or other means must be sufficient to 
allow the epoxy to pass into the fiber. As can be seen in Figure 1 the applied pressure will ensure that the epoxy mixture wraps around the fibers and thus a uniform epoxy fiber distribution structure is obtained.

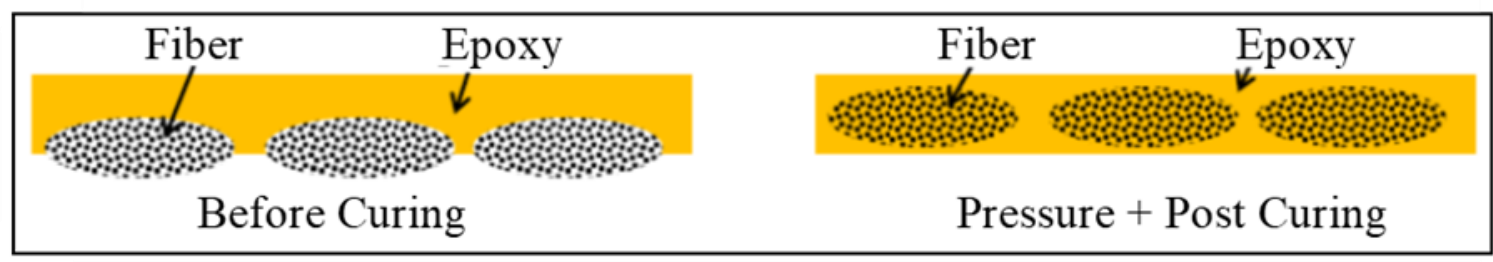

Figure 1 The epoxy mixture wraps around the fibers [16].

One of the important points to be considered while producing composites with prepreg is that the epoxy-rich prepreg surface is facing upwards, that is, in the direction where the pressure will be applied.

As can be seen in Figure 2 the order to be followed while producing is as follows.
- The separator layer, the blanket layer that accelerates the air flow, and the molding nylon are laid.

- Vacuuming process is carried out.

- It is placed in an autoclave or oven at the appropriate temperature for curing.

- Prepregs are laid on the mold that is desired to be shaped.

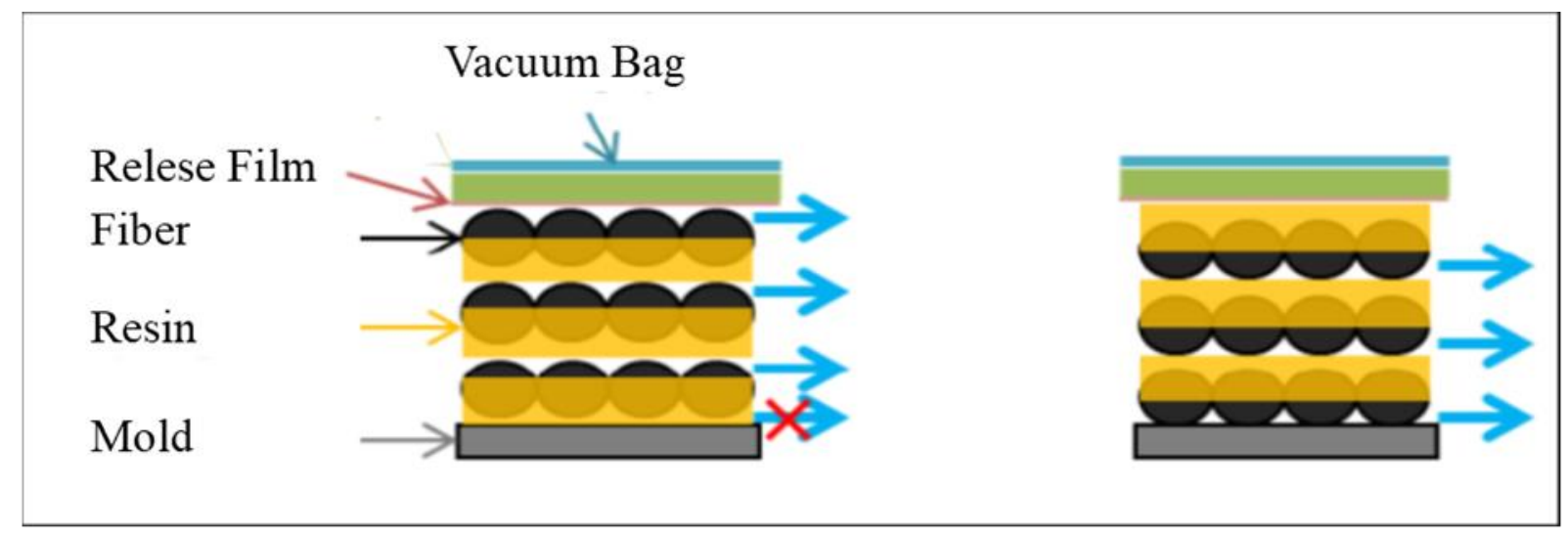

Figure 2 Prepreg production scheme [16]

For the production of aramid reinforced polymer matrix composite, prepregs supplied from Kompozitsan ${ }^{\circledR}$ were used. Aramid fabric has a plain structure and has an areal density of 300 $\mathrm{g} / \mathrm{m} 2$. The prepregs were produced with a hot press device as seen in Figure 3. The prepregs cut into the desired sizes were placed appropriately $(3 \mathrm{~mm})$ and cured in a vacuum environment for 90 minutes at $120^{\circ} \mathrm{C}$ under approximately $13-15$ bar pressure. Heating rate is set at $6^{\circ} \mathrm{C} / \mathrm{min}$. Since the applied pressure differs according to the number of sample layers to be obtained, the pressure was changed according to the $0.25 \mathrm{~mm}$ thickness, which is the final thickness that each layer will reach. In order to analyze the low velocity impact behavior of the polymer matrix composite, aramid based polymer matrix composites were produced by prepreg method with a thickness of $3 \mathrm{~mm}$ and a diameter of $90 \mathrm{~mm}$ and exposed to three different impact energies. Composite specimens were applied to the hemispherical tips with a radius of $10 \mathrm{~mm}$ and a weight of $5.045 \mathrm{~kg}$ with an impact energy of $15,30,45$ joules at room temperature, by giving velocities of $2.44,3.44,4.22 \mathrm{~m} / \mathrm{s}$. Low velocity impact test setup is presented in Figure 4. Density measurements of polymer matrix composites were made with Precisa ${ }^{\circledR}$ brand device (Figure 5) that calculates with Archimedes principle. 
European Journal of Science and Technology

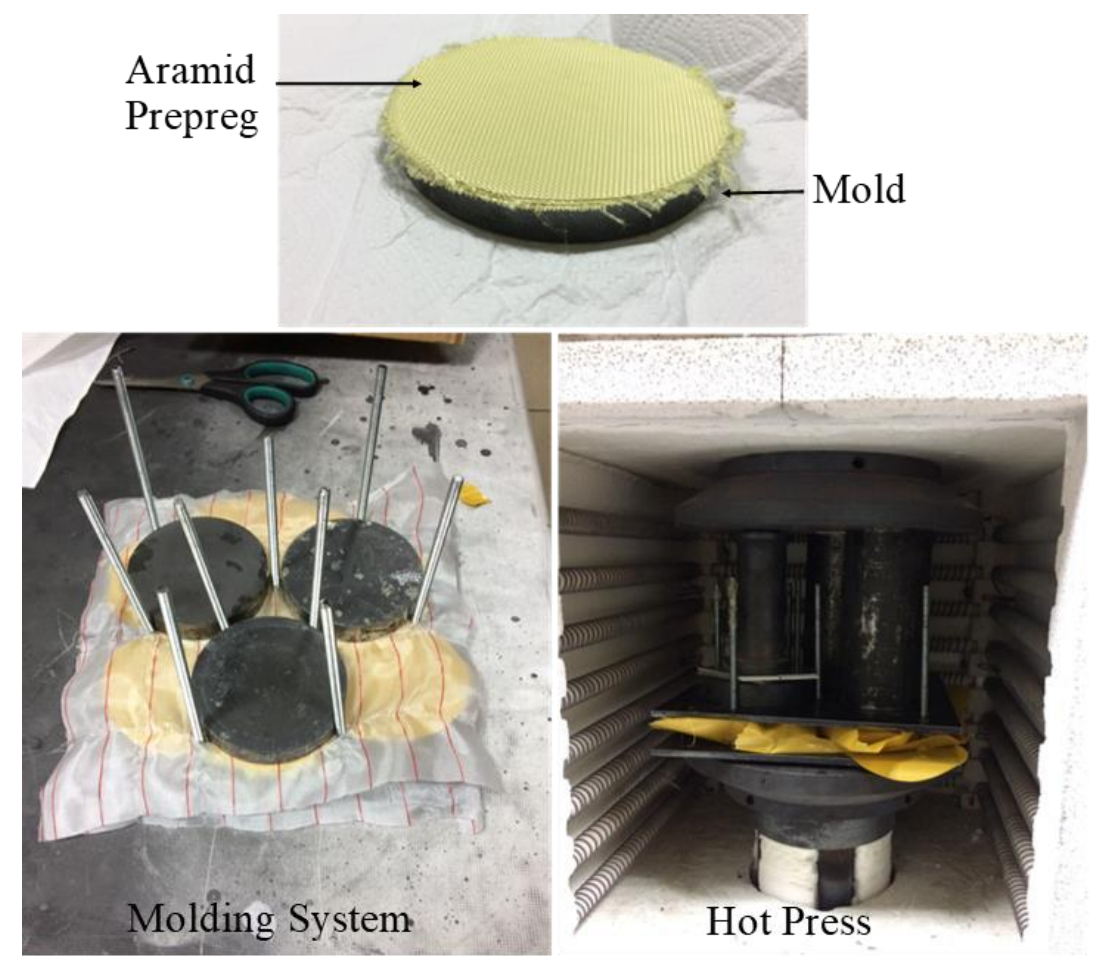

Figure 3 Production stages of polymer matrix composite with prepreg.

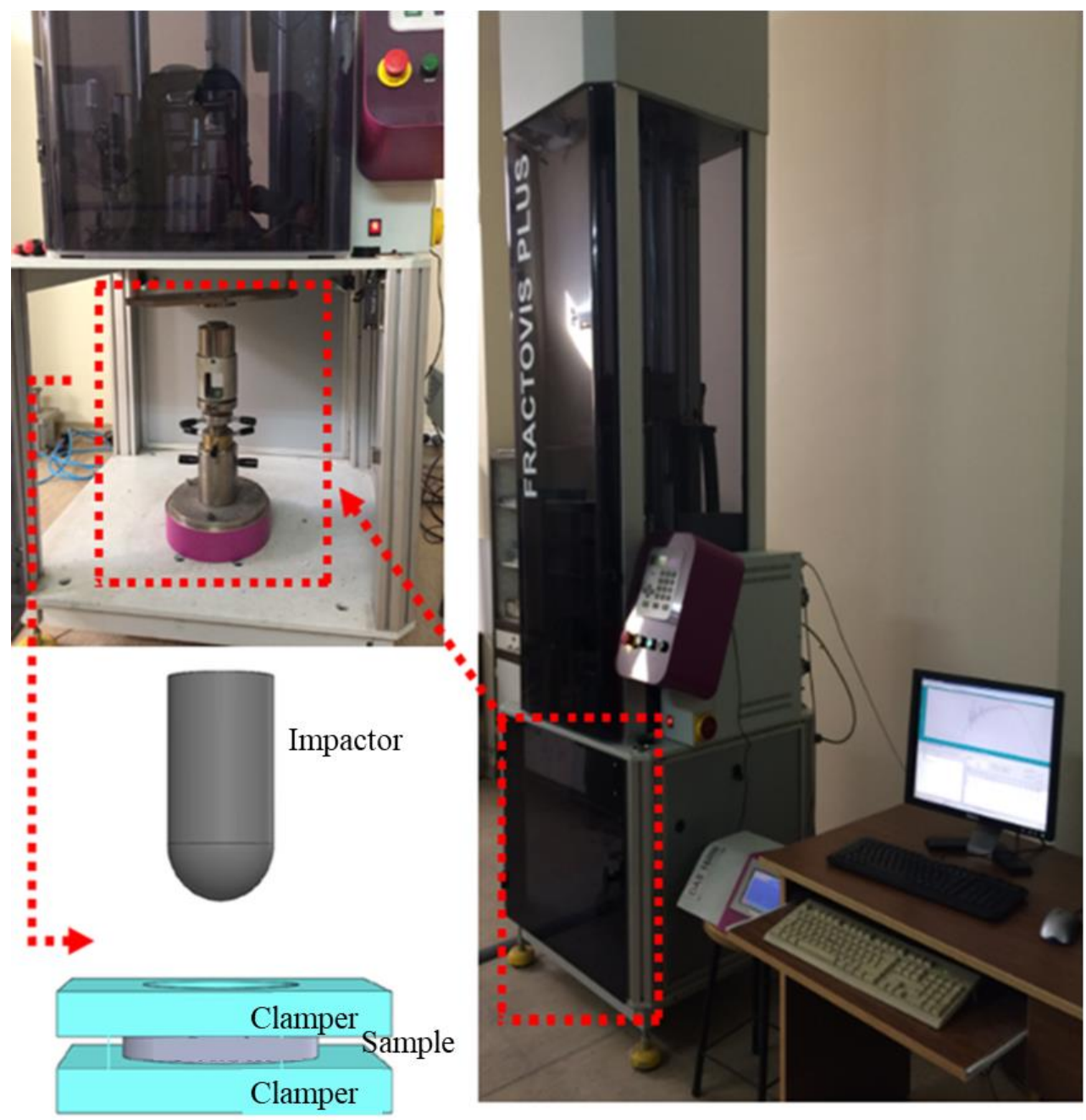

Figure 4 Low velocity impact test setup. 


\section{Results and Discussion}

Density measurements of composite samples were made on the basis of Archimedes principle as seen in Figure 5. The measurement results obtained are presented in Table 1. With this method, density measurement is performed on the basis of the following equation.

$$
\rho c=\frac{W a}{W a-W w} \rho w
$$

Here, $\rho c$ represents the density of the composite, Wa the weight of the composite in air, $\mathrm{Ww}$ the weight of the composite in water, and finally the density of water at $\rho s(1000 \mathrm{~kg} / \mathrm{m} 3)$. Three measurements were made and the arithmetic average was taken. Accordingly, the density of the produced composite was determined as $1,255 \mathrm{~g} / \mathrm{cm} 3$. This value is a very suitable result for structural applications.

\section{Table 1 Density measurement results.}

\begin{tabular}{|c|c|c|c|c|}
\hline Measurement & 1. & 2. & 3. & $\begin{array}{c}\text { Arithmetic } \\
\text { Mean }\end{array}$ \\
\hline $\mathrm{g} / \mathrm{cm}^{3}$ & 1.228 & 1.224 & 1.312 & 1.255 \\
\hline
\end{tabular}

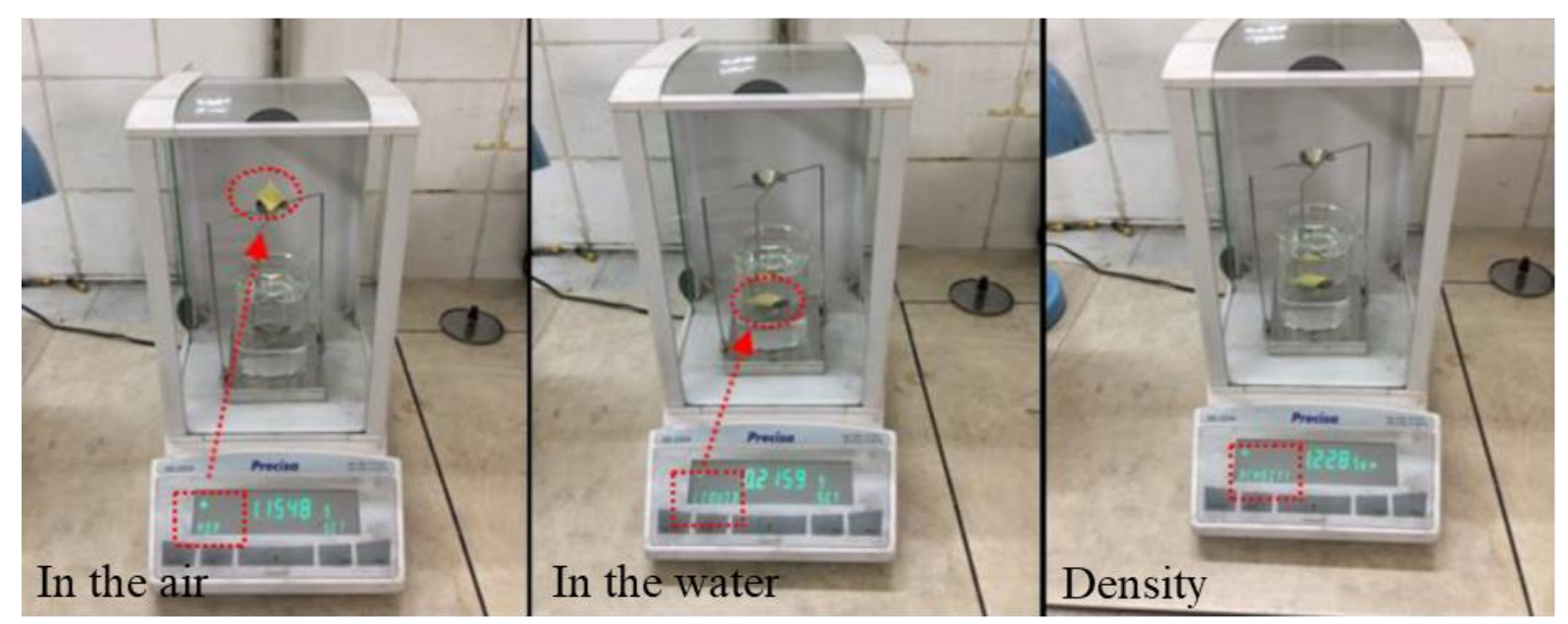

Figure 5 Density measurement steps.

For the analysis of the impact behavior of polymer matrix composites produced from prepreg, the results of the impact analysis performed at three different velocity were obtained as contact force time and energy time curves. The contact force time and energy time curves obtained by the impact test are given in Figure 6 and Figure 7.

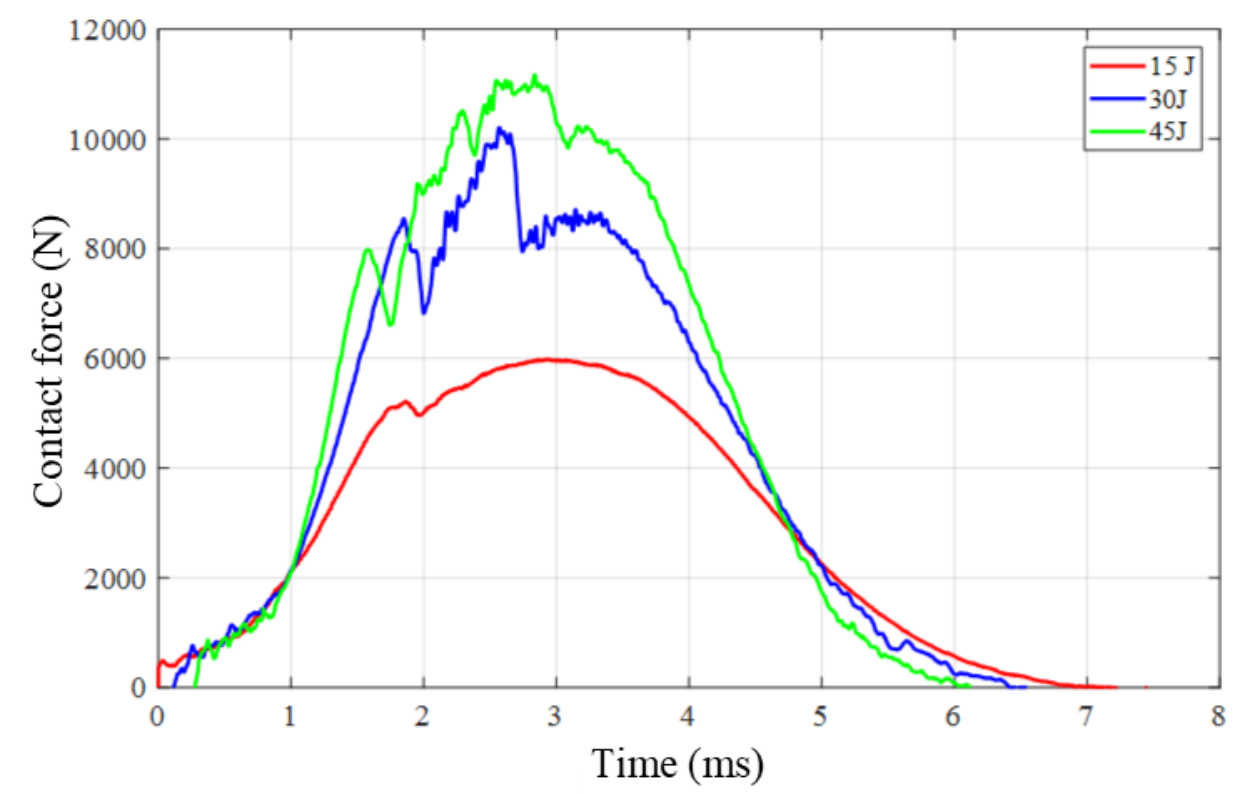

Figure 6 Contact force-time curves at three energies.

As can be seen in Figure 6, it has been determined that the contact force time curves become irregular as the impact energy increases. The maximum contact force is approximately 6,10 , and $11 \mathrm{kN}$, respectively, when 15,30 , and $45 \mathrm{~J}$ are applied. It can be clearly seen that the contact times decrease with the energy. When the curves are examined carefully, it is understood that when the impact energy is $15 \mathrm{~J}$, the composite material responds more e-ISSN: 2148-2683 uniformly to the impact, and when the impact energy is increased to 30 and $45 \mathrm{~J}$, matrix and fiber damages occur in the samples. The energy - time curves obtained from the impact test are presented in Figure 7. Here, it was determined that the ability of polymer matrix composite to absorb the applied impact decreased with the increase of impact energy in samples produced under the same conditions and having the same geometry. When $15,30,45$ 
$\mathrm{J}$ impact energy was applied to the samples, it was understood that the samples absorbed 13.5, 10 and $6 \mathrm{~J}$ energy, respectively. If expressed as a percentage, when $15 \mathrm{~J}$ energy is applied, the polymer matrix composite material absorbs $90 \%$ of this energy, while this rate is $33.3 \%$ and $13.3 \%$ when 30 and $45 \mathrm{~J}$ are applied, respectively.
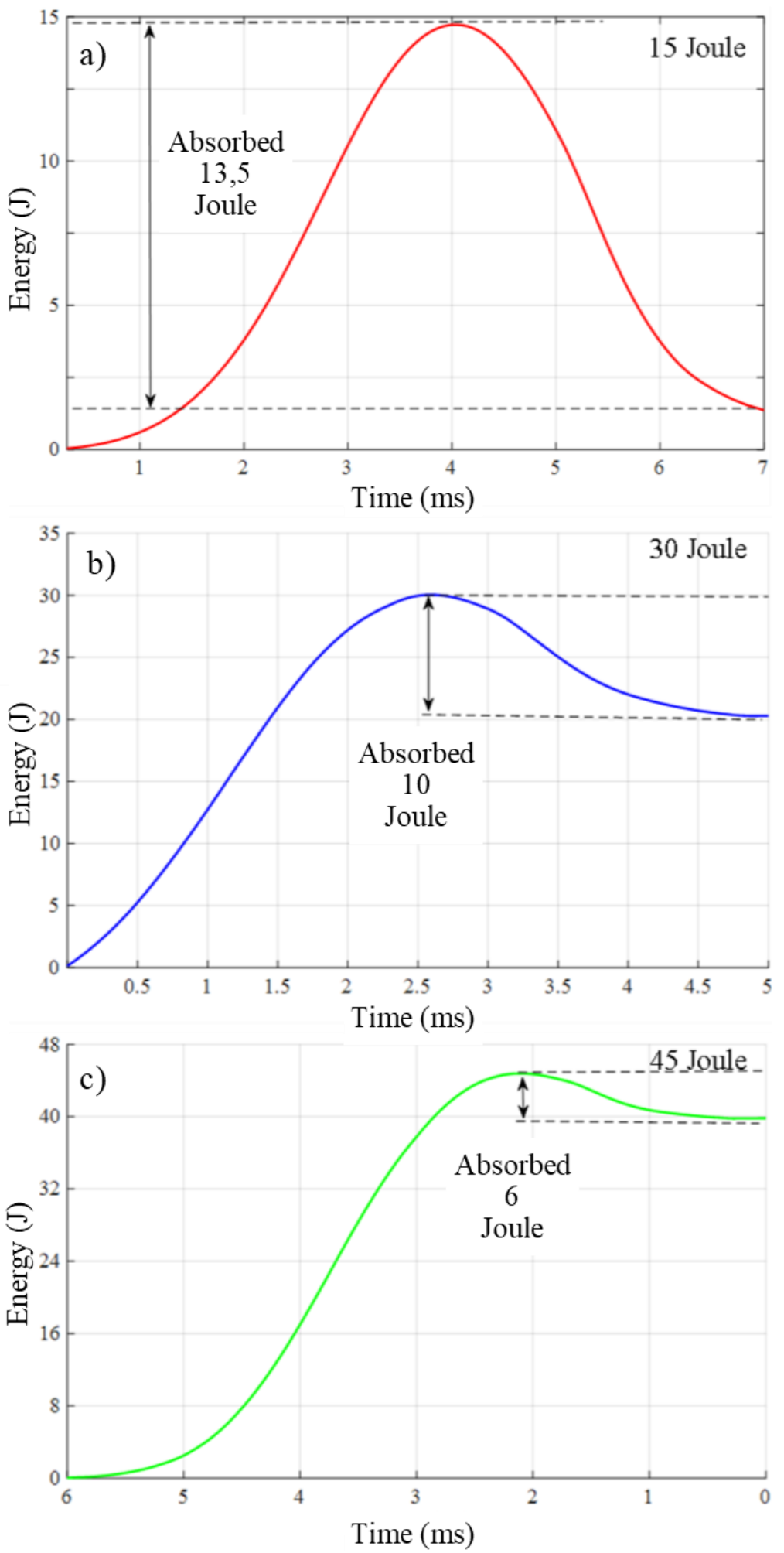

Figure 7 Energy-time curves of a) $15 \mathrm{~J} \mathrm{b)} 30 \mathrm{~J}$ and c) $45 \mathrm{~J}$ of polymer matrix composites.

The images taken from the front and back of the impacted samples are given in Figure 8. When the sample surfaces are examined, the damage in the matrix and fiber, which shows parallel results with the contact force - time curves, can be clearly seen. 


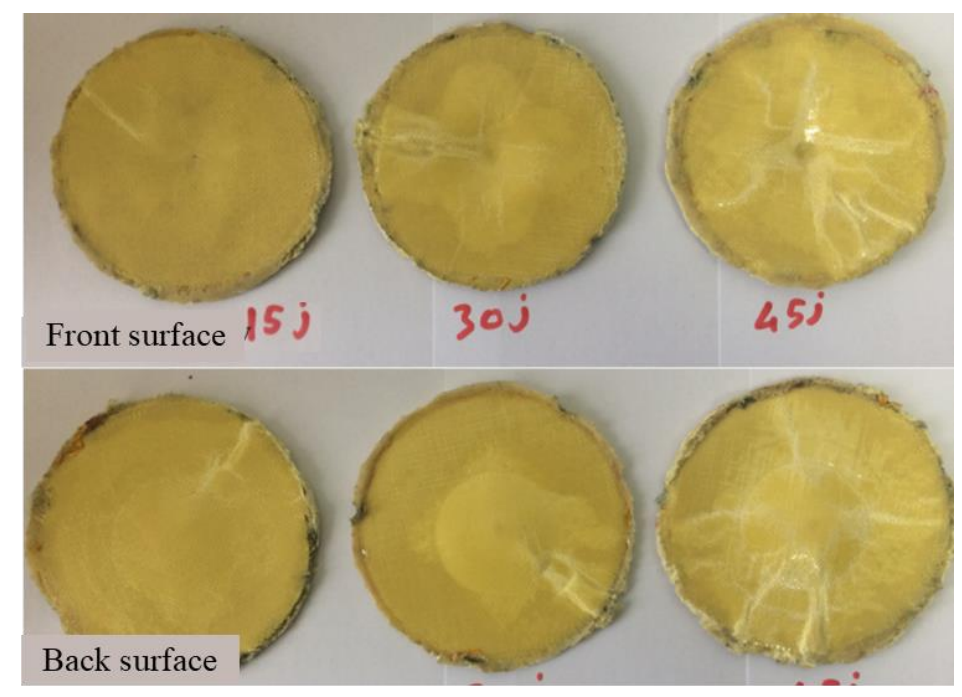

Figure 8 Damage images of PMK structures after low-velocity impact testing.

\section{Conclusions and Recommendations}

In this study, a new method was applied for the production of polymer matrix composites with prepreg. Unlike the classical autoclave method applied in production with prepreg, with this production method, the prepregs were carried out in the pressvacuum-curing process in the oven. With this method, $3 \mathrm{~mm}$ thick and $90 \mathrm{~mm}$ diameter aramid reinforced polymer matrix composites were produced and impact tests were carried out at 15 , $30,45 \mathrm{~J}$ energy values. According to the contact force time and energy time curves obtained from the impact tests, the impact resistance of the composite materials as a result of the impact at different velocity was revealed. Accordingly, an increase in the maximum contact force was detected as the impact velocity increased in the composite samples. Besides contact time decreas. In addition, as the impact velocity increased, the irregularity in the characteristic curves began to increase. The amount of energy absorbed by the composite samples was determined. Accordingly, the energy absorbing abilities of the composites show a decrease as the impact velocity increases.

\section{Acknowledge}

Financial support for this study was provided by the Division of Scientific Research Projects (BAP), Erciyes University, TURKEY (Project No. FDK-2018-8658).

\section{References}

[1] Aktas M., Atas C., Içten B M., Karakuzu R., 2009. An experimental investigation of the impact response of composite laminates. Composite Structures, 87, 307-313.

[2] Bouvet C., Rivallant S., Barrau J.J., 2012. Low velocity impact modeling in composite laminates capturing permanent indentation. Composites Science and Technology, 72, 19771988.

[3] Belingardi G., Vadori R., 2002. Low velocity impact tests of laminate glass-fiber-epoxy matrix composite material plates. International Journal of Impact Engineering, 27, 213-229.

[4] Kosedag E., and Ekici R., 2019. Low-velocity impact performance of $\mathrm{B}_{4} \mathrm{C}$ particle-reinforced $\mathrm{Al} 6061$ metal matrix composites. Materials Research Express, 6, no. 12, doi:10.1088/2053-1591/ab5815.
[5] Ekici R., Kösedag, E., 2017. Comparison of the low-velocity impact behaviors of $\mathrm{SiC}$ and Pumice particle-reinforced metal matrix composites. International Journal of Mechanical and Production Engineering, 5 (10), 101-105.

[6] Kösedağ E., Ekici R., 2019. Partikül Takviyeli Metal Matrisli Kompozitlerin Darbe Davranışları Üzerine Bir Derleme. Niğde Ömer Halisdemir Üniversitesi Mühendislik Bilimleri Dergisi 8, 384-393.

[7] Berk B., Karakuzu R., Icten M., Arikan V., Arman Y., Ataş C., Gören A., 2016. An Experimental and Numerical Investigation on Low Velocity Impact Behavior of Composite Plates. Journal of Composite Materials, 50 (25), 3551-3559.

[8] Xiaofei L., Hongneng C., Pengfei Y., FeiJiao, Xuecheng H., 2017. Failure Analysis of Composite Laminate under LowVelocity Impact Based on Micromechanics of Failure. Composite Structures, 163, 238-247.

[9] Sayer, M., 2009. Hibrit kompozitlerin darbe davranışlarının incelenmesi, Doktora Tezi, PamukkaleÜniversitesi Fen Bilimleri Enstitüsü, Denizli.

[10]Belevi M., İnançer G., 2004. Darbe ve Ortam Şartlarının Kompozit MalzemelerinMekanik Özelliklerine Etkileri. Makine Teknolojileri Elektronik Dergisi, 4, 9-31.

[11]Gustin, J., Joneson, A., Mahinfalah, M., Stone, J., 2005. Low velocity impact of combination Kevlar/carbon fiber sandwich composites, Composite Structures, 69, 396-406.

[12]Uyaner M., Kara M., Ataberk N., 2007. E-Cami/Epoksi Tabakalı Kompozitlerin Düşük Hızlı Darbe Davranışına Numune Boyutlarının Etkisi. 8. Uluslararası Kırılma Konferans1 Bildiriler Kitab1, 361-368.

[13]Yapıc1, İ., Yapıc1, A., 2012. E-Cam1/epoksi tabakalı kompozitlerde düşük hızlıdarbe davranışının sonlu elemanlar yöntemiyle incelenmesi. Niğde Üniversitesi Mühendislik Bilimleri Dergisi, 1(2), 48-60.

[14]Salehi-Khojin A., Bashirzadeh R., Mahinfalah M., NakhaeiJazar R., 2006. The role of temperature on impact properties of Kevlar/fiberglass composite laminates. Composites: Part B, 37, 593-602.

[15]Özes Ç., Taşkın A.E., 2016. Jüt Kumaş ve Yün Keçe Esaslı Kompozitlerin Darbe Davranışının Belirlenmesi. Dokuz Eylül Üniversitesi Mühendislik Fakültesi Fen ve Mühendislik Dergisi, 18 (54), 513-520.

[16]Danzi, M., 2017. Manufacturing of Polymer Composites OOA Prepreg Technology, Laboratory of Composite Materials and Adaptive Structures, ETH Zürich. 